\title{
$46, X Y$ disorder of sex development due to 17-beta-hydroxysteroid dehydrogenase 3 deficiency
}

INSERM

\section{Source}

INSERM. (1999). Orphanet: an online rare disease and orphan drug data base. 46,XY disorder of sex development due to 17-beta-hydroxysteroid dehydrogenase 3 deficiency. ORPHA:752

17-beta-hydroxysteroid dehydrogenase isozyme 3 (17betaHSD III) deficiency is a rare disorder leading to male pseudohermaphroditism (MPH), a condition characterized by incomplete differentiation of the male genitalia in 46X, Y males. 